\author{
Aleksandra Žeželj Kocić \\ University of Belgrade \\ Faculty of Philology \\ Belgrade, Serbia
}

\title{
ERNEST HEMINGWAY: RECONCEPTUALIZATION OF GENDER
}

\begin{abstract}
This essay focuses on the way as to how Ernest Hemingway's novel The Garden of Eden understands the concept of gender. Namely, we are concerned with the representation of human character in Hemingway's text, especially with how characters are constructed along lines of gender and sexual behavior. Hemingway's interest in transgressive sexuality, with its emphasis on gender switching, indicates an edge towards his subversion of traditionally patriarchal ideas he is often taken to embody, while his embrace of border-line matters displays a specific dialogue with men's and women's multifold representations.
\end{abstract}

Key words: Ernest Hemingway, gender, transgression, subversion, re-thinking, border-lines.

The body of itself is clean, but the caged mind is a sewer inside, it pollutes, $O$ it pollutes ...

(D. H. Lawrence, "Obscenity")

Eve has many faces.

(R. Robbins, "Will the Real Feminist Theory Please Stand Up?")

E-mail address: aleksandra.zezelj@gmail.com

${ }^{* *} \mathrm{PhD}$ candidate 


\section{Introduction}

There is much evidence that from 1946 to 1958 Hemingway had been working on what was to become The Garden of Eden (Spilka 1995: 1), i.e. well before the novel got posthumously published in 1986. Even such a heavily edited version proved to be a "published literary crime" (Solomon in Fantina 2005: 13) since it mostly tackles the androgynous sex-reversal experiments of Catherine and David, a couple in 1920's France who decide to further complicate their married life by letting another woman, Marita, enter their already lost paradise.

This essay focuses on the way as to how this particular novel understands the complex concept of gender and how its characters are constructed along the lines of gender and sexual behavior. To this end, the edge is not only taken to denote the line where one thing stops, but also a move in the direction of something other than itself. Namely, Hemingway's interest in transgressive sexuality - with emphasis on gender-switching through hair-dyeing, hair-cropping, fashion, tanning, drinking, talking, writing, etc. - indicates an edge towards his subversion of traditionally patriarchal ideas he is often taken to embody. Albeit the connection between writing/creativity and sexuality/desire has always been present in his work, The Garden of Eden is specifically said to be about "the writer's bravery in his daily struggle to transcend his terrible dependencies and passivities" using his own hurts (Spilka 1987: 47).

The great discrepancy between the published and manuscript versions of the Hemingway's text in question becomes an issue the majority of Hemingway's critics and readers alike cannot still digest. To our mind, the publisher Tom Jenks is almost excusing himself for having made some cuts in the manuscript and some routine editing corrections, maintaining that "in every significant aspect the work is all the author's" (in Hemingway 2003: vi). Charles Scribner, Jr. accentuates the fact that even though "this novel may be seen as a departure from Hemingway's usual themes - as an intensive study of the mental state of an intelligent woman uncontrollably envious of her husband's success as a writer with a yearning to change her gender," - it remains Hemingway's typical work in his forever profound study of character and Conradian primary interest in the effect that events have in the minds of individuals concerned (vii; my emphasis). The published version excludes the alternate plot of yet another couple, Nick and Barbara Sheldon, as well the third plot featuring Andrew Murray. 
Despite the fact that Hemingway left the novel's ending(s) unresolved, it is ascertained that the optimism of the final chapter is not something he had in mind since it runs counter to the pattern of tragedy Hemingway had been preparing as he worked through different versions (Fleming 1989: 263269). Opting for a so-called happy ending, the publishers offer a sanitized novel's variety (Comley and Scholes 1992: 283) in which innocence has been recaptured. Surely, a more somber ending would have done better justice to ever-present darker reflections of Hemingway's art.

The episode where the Rodin's statue of two lesbian lovers making love further changes the couple's outlook on life ${ }^{1}$ is conspicuously cut out from the novel's narrative, thus erasing its concern with forbidden mysteries and disturbing sexual ambiguities (Spilka 1987: 35). The statue from the Gates of Hell, based on Ovid's Metamorphoses and Baudelaire's Les Fleurs du Mal would have been one of the nicer signposts of a sea change ${ }^{2}$ as an inner journey the protagonists set out on (Spilka 1995: 285), as well as of their metamorphic powers. So, the moving artistic creation would have served as a public inspiration for troubling private changes. Still, the outward manifestations of inner transmutations the protagonists do go through - e.g. experiments with hair-length, hair-style, hair-color, clothes, and finally, words, gestures and deeds - are a fair proof of the blurring of gender roles Hemingway was always concerned, if not obsessed, with. ${ }^{3}$

${ }^{1}$ In the manuscript version Catherine asks David if he remembers the statue showing two lesbian lovers one of whom looks like a man but is actually a woman with a short haircut like Catherine's. Also, it may be of note that Hemingway chose not to depict with any exactness the lovemaking between two sexual seekers after dangerous knowledge (Spilka 1995: 286).

2 The term sea change is taken from Ariel's song in The Tempest by William Shakespeare which is ultimately about a creative process of transforming life into something more enduring which is art (Fleming 1996b: 51-52). Also, beware of Hemingway's short story "The Sea Change," printed within Winner Take Nothing (1933), where a woman leaves her man for another woman. The story thus perfectly shows the uninterrupted thread of Hemingway's concern with gender switching.

${ }^{3}$ In no way is this a conclusive list of cuts made in the published version of the novel, since this essay does not specifically deal with the novel's possible multiple endings. However, the most important meaning implications of The Garden of Eden's published and manuscript versions will be further explored in the essay's body text under separate thematic headings. 


\section{The Contexts}

At this stage, it is of importance to provide a basic historical and biographical backdrop to Hemingway's work since psychological teachings must be supplemented by other contexts as well, if we are to fully grasp the richness of Hemingway's views.

Hemingway was witness to a major shift from Victorian to modern age. The $19^{\text {th }}$ century clearly differentiates between the male sphere presupposing emotional and moral toughness, and the women's sphere which implies purity, piety, domesticity and submissiveness. The 1920's mark a modern New Woman, with her loosening of morals, (tom)boyish appearance and behavior, who, in fact, becomes a composite figure of flapper's sexual freedom, feminist assertiveness and traditional domestic femininity. Needless to say, this idea heavily contributed to Hemingway's image of an ideal woman. The liberation from Victorian teachings at the time provides an opportunity for people to turn to popularized versions of Sigmund Freud or Havelock Ellis. Furthermore, postwar feminism is prominent in 1920's Paris with Gertrude Stein as a legendary lesbian literary hostess. A shift in gender constructions and the societal effects of such a shift are clearly visible following the Great War (Sanderson 1996: 172175). The conflicted gendered cultural conflict of the turn of the century shaped Hemingway who seems to have sealed his mother's independence and social activism as evidence of her unfeminine desire to dominate, emasculate and ultimately lead to his weak father's suicide (Barlowe 2000: 124). The notions of appropriate female behavior get forever intertwined with the newly established notions, so women's hysteria, invalidism ${ }^{4}$ and a career of nursing motherhood get replaced by short-haired, virile women's aggression and assertiveness.

Moreover, the virtually all-male terrain of High Modernism gets panicked by changing social conditions - the competition by female writers, the growing openness of gay cultures and a feminized mass culture (Strychacz 2008: 1). Hemingway's work needs to be seen as an illustrative mixture of such broader changes and his upbringing that was mostly woman-defined (Wagner-Martin 1991: 323). Being immersed from

\footnotetext{
${ }^{4}$ Invalidism was common in the $19^{\text {th }}$-century America and it was almost a career for women. Namely, invalidism controlled these women's lives who were prone to headaches, fainting spells and stomach ailments. Hadley, Hemingway's first wife, was, in this respect, seen as a true woman (Barlowe 2000: 132).
} 
boyhood in Victorian literature with its roles of men and women clearly defined, and witnessing new cultural developments, Hemingway develops a line of anxiety about the gender lines that is going to glue to him, overthrowing the simplistic wound or code-hero theories about his art. The revising of Hemingway Text opens up new interpretations that seem to increasingly favor the overlapping connection between his biography ${ }^{5}$ and his work. The dynamic interrelationship between his fiction and his life recalls the "intentional fallacies" he suffered from (Lovell Strong 2002: 191), with lines between his personal life and his fictional creations never carefully drawn. Thus, The Garden of Eden gets patently self-reflexive in its ambivalent portrayal of androgynous sibling-like twinnings, instances of female manipulation and men's terrible dependency and vulnerability (Spilka 1987: 39).

\section{Hemingway reinvented}

The application of Judith Butler's theory of gender-as-performance and Bertolt Brecht's concept of the gest ${ }^{6}$ proves valuable in shedding new light on Hemingway's work. As an alternative to pro-feminist approaches, this line of interpretation unfolds a subversive and disruptive potential of male modernists including Hemingway himself (Strychacz 2008: 3).

Thus, gender is seen as a fluid, contradictory and conflicted function of theatrical performance, in forever-temporary negotiations of meaning. If gender is altogether an unstable category, the concept of "masculinityin-performance" then erases the principle of authentic/hegemonic masculinity, paving way for alternative, plural masculinities (Ibid: 13-21). Gendered identities are always in process, always repeated, which The Garden of Eden amply shows. The unsettling of what seems to be natural

\footnotetext{
5 To mention a few useful facts: his mother's twinning of Ernest and his sister Marcelline, her domineering feminist inclinations; his father's repetitive depression bouts and eventual suicide; his wives' alleged lesbianism, hair-dyeing/hair-cropping, their manipulative ways; Hemingway himself is said to have dyed his hair bright red on May 14, 1947. (Lovell Strong 2002: 190) during the composition of The Garden of Eden, claiming that he had mistaken the bottle for his ex-wife Martha's old shampoo (Spilka 1995: 291).

6 The gest is a dramatic strategy whose purpose is to represent and make strange a particular set of social conditions and thus reveal an otherwise covert structure of power (Strychacz 2008: 3).
} 
using a technique of defamiliarization ${ }^{7}$ denotes "the trope of performance" with its constant blurring of copies and originals. Various critics and readers have been searching for "one stable, universal and self-evident masculinity" in Hemingway's text, not ready to face its "gradual unseating of patriarchal manhood" (Ibid: 72-75). A powerful stereotype of virile, heterosexual and aggressive masculinity is at stake if we are to consider its inner theatricality as the newly given fact. As Butler maintains, "identity is a compelling illusion, an object of belief," whereas gender identity is a performative accomplishment compelled by social sanction and taboo (2004: 901). There is no preexisting identity by which an act or attribute might be measured. Rather, gender reality is created through sustained social performances (Ibid: 908).

Furthermore, Fantina holds that after some revisionist criticism of Hemingway's work, ${ }^{8}$ Hemingway can "no longer be interpreted onedimensionally as the prototypical he-man" (2005: 2). It is vital that we look beyond the picture constructed about him and realize "a male masochism's subversive potential as a threat to patriarchal notions of gender roles." Hemingway employs a dual masculinity comprising both traditionally stoic masculine values and masochism as their counterbalance. In both his life and fiction, Hemingway makes use of two contrasting impulses of playing the macho hero who controls the actions of women, while simultaneously surrendering to a masochistic desire to yield to a willful, dominant woman (Ibid: 8-11). The decline of Victorian values in the wake of World War 1 does not imply their complete erosion in Hemingway. More likely, his conservatism remains strong despite alternative sexualities he embraces. $\mathrm{He}$ is still separating the social from the bedroom domain making distinction between the public and the private areas of control. Thus, David is uncomfortable at Catherine's violating their secret of gender rolereversals performed in the dark, when she reveals their games to somebody else. ${ }^{9}$ Still, there is a wish for merging identities, "a desire for symbiosis," a blurring of identities, "an unattainable fusion" that Hemingway and his characters often demonstrate (Ibid: 47-49). Though he never overcame "the cultural baggage of Victorianism," Hemingway is believed to have had

\footnotetext{
7 B. Brecht's Verfremdungseffekt.

8 R. Fantina mentions M. Spilka, C. Eby and D. Moddelmog at this point.

9 Catherine reveals their secret to Colonel John Boyle, who has already sensed the change himself (Hemingway 2003: 63; my emphasis). David feels uneasy about her starting to show her/their dark things in the light (67).
} 
"an unconventionally submissive and masochistic side to his heterosexual nature (Ibid: 83; 89)." David and Catherine can be seen as two sides of Hemingway wrestling with one another (Ibid, 158), with the public myth of machismo and homophobia ${ }^{10}$ walking hand in hand with alternative varieties, if not perversions, of sexuality.

Also, Spilka's interpretation proves invaluable in sketching Hemingway's "wound of androgyny" that comes of his identification with women and the female within oneself, because of which the author felt an almost intolerable vulnerability, a hidden emasculation, a secret loss of male identity, a self-betrayal (1995: 122). Bearing this in mind, he recognizes the secret muse within himself first as Catherine - a devilish woman inclined towards role reversals and lesbianism, then as Marita - a supportive woman who encourages his recovery (Ibid: 3). Spilka accentuates the overwhelming connection between Hemingway's androgynous corruptions with both real and fictional wives and mistresses and his writing strengths (Ibid: 296). It seems probable that Hemingway thought that this androgynous complicity in the corruption increased his artistry. The Garden of Eden is seen as Hemingway's contribution to "the theory of androgynous creativity" (Ibid: 333), which is paradoxically proposed by Virginia Woolf, one of Hemingway's literary enemies. ${ }^{11}$

Hemingway's stories may also be read as "commentaries on sexual and cultural differences," as Comley suggests (2002: 207). Hemingway keeps his binary oppositions in place, but he is concurrently fascinated with the possibilities of experiencing a shift in genders (Ibid: 212). He questions the gender binarism, unsettles the Victorian notions, but he also feels great guilt and shame over possessing such feelings. The fixed stability between the male and female domains is definitely shattered in both his life and work, no matter the fluctuating quality of his gendered vision. The "interesting tension between revelation and concealment" exhibits a peculiar gender anxiety exposing "multiple forms of desire," while depicting the ambiguities of both male and female identities (Kennedy 1991: 191-194). Consequently, and luckily for his readers, Hemingway's gender issues will never be resolved.

${ }^{10}$ David does not like the idea of both Catherine and himself playing boys' roles at the same time (Hemingway 2003: 67).

${ }^{11} \mathrm{~V}$. Woolf explicates the workings of an androgynous mind in her famous A Room of One's Own. She is also known for her attack on Hemingway's style of writing. 


\section{The lost Eden}

Hemingway's quest for personal wholeness is re-enacted in his motif of the lost paradise through which he was seeking to recapture "the happiness of the garden that a man must lose" (Sanderson 1996: 175). His fantasy of a paradise on earth gets shattered by men's and women's inability to dwell in the garden of Eden. David's and Catherine's discovery of evil makes the primal Edenic complementarity impossible. The perfect and harmonious unity of Adam and Eve falls into sin when their eyes are open to sexual difference, giving them a consciousness of their own incompleteness (Kennedy 1991: 202-203). Hemingway's revision of the biblical Garden of Eden plot is best seen in the manuscript scene of the entitled novel "when the two couples are moved by the statue of metamorphic love so that they begin with their own androgynous experiments, in both of which the girl is the active agent, the Eve-like temptress" (Spilka 1995: 287). Moreover, marriage breaks "the individual will for self-possession" through a partner's many-sidedness, which in turn leads to "the disquieting dependence upon a personality that can never be seen in its entirety" (Jung 2003: 50; 53). The allure of androgyny displays Hemingway's fascination with gendered otherness and its constant performative and theatrical value.

David in Hemingway's The Garden of Eden writes two narratives, the first of which is the marital story of his life with Catherine who categorically insists on this being the main narrative in his life as a writer. The other narrative is "the boyhood tale of men without women," which David attempts as "an act of manly resistance to the corruptions of his androgynous married life" (Spilka 1995: 299). David "symbolically kills Catherine" (Burwell 1993: 200) through his neglect of the honeymoon story since his "compartmentalized psyche" does not allow masculine and feminine to mingle (Ibid: 203). So, his African story presupposes a masculine mode in his battle against a feminine mode of experiencing. In his (and Hemingway's) vision of "the incompatibility of sexual tenderness and artistic strength" (Scafella in Burwell 1993: 217), David believes that he will protect his writing if only he could successfully repudiate women from it. The androgyny he succumbs to through his various roles, activities, physical appearance and sexual positions further accentuates the hopelessness of such a wish. His masculine writings get literally and metaphorically burned by Catherine, so as only to be equally rescued by 
Marita later on. Ironically enough, David's creative/phallic power redeems itself with the aid of a woman's touch.

\section{Honeymoon narrative}

Since David's honeymoon narrative deals with the story of his being married to Catherine, this section will primarily focus on her overbearing character. Throughout the course of the novel, Catherine is constructed both as male and female. In this respect, Hemingway plays with our stereotypical notions of masculinity and femininity.

First, Catherine feels shackled in the patriarchal text, caged within the narrow feminine role the society prescribes for her. Feeling trapped within the limitations of her gender, she commits "seemingly destructive acts as an act of re-vision" (Lovell Strong 2002: 191). ${ }^{12}$ Because she believes her position to be claustrophobic for her unattainable desire, she adopts various roles outside her wifely capacity. Namely, she alternately becomes a brother, a husband, a girl, a good girl, a boy. In this respect, the degrees of her restriction are fluctuating. Having destroyed a Victorian angel-in-thehouse within herself, Catherine still keeps a little bit of Freudian shame, always apologizing to her husband for her crossing the lines of female prototypical decency, begging him for forgiveness and inquiring about his health. She "inhabits an unstable territory between binaries, which is a place that breeds tension, anxiety and insecurity" (Ibid: 192). This way, she is deconstructive rather than destructive, her gender proving to be a dynamic entity. Willingly or not, Hemingway created a feminist character in her. She is "a divided self", wishing to escape the socially imposed category of a woman (Ibid: 193). She purposefully plays a female-as-hysteric stereotype, picking on fights with her husband, uncontrollably yelling at him, having mood-swings and wishing to have a baby (Hemingway 2003: 70). Thus, The Garden of Eden paints gender as a temporary quality, prone to constant revisions. "The weight of cultural normalcy" (Lovell Strong 2002: 198) forces her to publicly act as a wife uncontaminated by inadequate yearnings. Her over-spilling of female desire evokes jouissance within the male narrative, while her transgression of "sexual fantasizing" takes the

\footnotetext{
${ }^{12}$ It is noteworthy that A. Lovell Strong compares the character of Catherine with the wife in C. P. Gilman's The Yellow Wallpaper, and David to John, a husband who stifles the wife's creativity (2002: 191-192).
} 
form of madness (Spilka 1995: 304). Catherine becomes the corrupting Devil ${ }^{13}$ whose insistence on differentiating between variety and perversion does not take root with David/Hemingway. Hemingway often "blurred the line between evil and madness" (Ibid, 305), possibly in his final inability to overcome women's inherent duality he was so good at depicting. Though much more sympathetic to women than he was given credit for, Hemingway "feminized the things that hurt his career" (Sanderson 1996: 191) ${ }^{14}$ and so made Catherine burn David's masculine text. Catherine is portrayed as "a female who paralyzes the man's creativity" (Fleming 1996b: 87).

In contrast, Catherine is delineated as a phallic man through her initiative in the bedroom domain, masculine fetish of practicality, dominance, control, interest in sexual experimentation, financial independence and intellectual superiority. As a good conversationalist, she balances David's writing with her own rhetoric and voices her own voice. Still, through her character, Hemingway underlines that "manhood is primarily a function of staging rather than maleness," since Catherine becomes male, "looks like a boy but is not." Catherine constructs herself as a man, "Catherine-as-a-man is a trope" (Strychacz 2003: 215-216). For instance, "her appropriation of the phallus" (Fantina 2005: 62) is outwardly done through her incessant changing of hair-style which stages "hair as a symbolic female phallus" (Eby in Fantina 2005: 53), but only with a simultaneous representation of "hairdressing as a cliché of unmanliness" (Ibid: 110), both for her and David.

Furthermore, she refuses to be a woman who will give up her own identity and become absorbed into her male. But, since "women are never central to any of Hemingway's works on their own terms," Catherine is, at the end of the novel, made to leave the narrative and give up her husband to Marita. Hemingway thus effuses his "fantasy of an idealized sexual union" in his discourse of desire (Wagner-Martin 2002: 56-57). Marita triumphantly stifles her transgressive lesbianism and becomes a submissive, new wife who rekindles David's artistic potency. Being the second Other in the male

${ }^{13}$ David addresses her as Devil throughout the course of the novel. Catherine refers to herself as Peter at some point (Hemingway 2003: 17), and she will not accept the socially accepted forms of address, such as Darling, Dearest, My very dearest, etc. (Ibid: 27; my emphasis).

${ }^{14}$ In a letter to M. Perkins of June 7, 1929, Hemingway compares censorship to emasculation, which is a proof that he thought of writing in gendered terms. He felt the publishing industry threatened to stigmatize his profession as effeminate (in Sanderson 1996: 183). 
- female binarism, and a woman supportive of her husband, Marita clearly typifies a difference within difference of feminist criticism. Her marital over-pampering of David applauds her with the gift of heterosexuality that Hemingway extolled so much despite his ample investigations into the queer territory. As a "good wife," Marita is "dutiful, accommodating and living according to the standards of wifeliness" (Lovell Strong 2002: 197; my emphasis). Logically enough, she gets submerged and silenced by an overbearing masculine narrative. While Catherine performs feminine hysteria, "thus becoming the stereotype she despises," Marita practices "quiet but effective subversion," winning David over by "performing his fantasy of the feminine" (Comley 2002: 216).

\section{Masculine counter-narrative}

David is a Hemingway's portrait of an artist as a husband and a son. Still, he defines himself in terms of his writing, not his being married. His masculine narrative is, in fact, "writing the father" (Fleming 1996b: 151), where he narrates the African story of the elephant-hunt with his father and his father's friend when he was 8 years old. This counter-narrative of his is an exclusively male territory, not to be occupied by women. Therefore, David locks himself up in a room at the far end of their hotel so that he could write undisturbed by female influence. The locked room is a patent symbol of a self-willed isolation of a writer, which is one of the topics Hemingway explores throughout his writing career. David is, thus, one of Hemingway's writer-characters who serves the high purpose of delineating problems that any true writer is bound to encounter in his life, to name but a few: writer's ruthlessness in subordinating his real to his artistic life, his inhuman isolation and insensitivity to others, his irresistible compulsion to work, the perversion of living in his fiction, artistic and sexual impotence, his loneliness, writer's block and artistic paralysis, his inspiration, etc. (Ibid: 145-171).

It is vital to acknowledge that Hemingway masculinized the act of writing itself (Fantina 2005: 159) choosing to ban women from the paradise or show them as having a damaging effect on a writer's creativity. This is best shown in Catherine's burning David's stories or her detrimental influence on his artistic strength. In contrast, in one of his interior monologues, after having made love to Catherine at the beginning of their happiness together, 
David ponders how writing is unimportant in comparison to truly loving a girl (Hemingway 2003: 13). This state of mind soon dissolves when David demonstrates what his main narrative actually is. He dismisses Catherine's participation as intrusion into his writing and inhabits the room as "a place of disengagement from sexual and social involvement" (Burwell 1993: 204). The cessation of honeymoon narrative enables his "paradigm of the paternity of literary text" (Ibid: 208). Also, Hemingway seems to be using David as a mouthpiece of his own insights on writing. For instance, the story starts with no difficulty when it is ready to get written, and then should be left till the next day when a writer hits it fresh when the necessity to write comes to him (Hemingway 2003: 93). Also, if you do not finish a story, nothing is worth a damn (Ibid: 108)! In her belief that David feels his masculine story intensely, Catherine, almost angrily, says: "It's a book you have to die to write and you had to be completely destroyed (Ibid: 112)."

However, the expulsion of Catherine from writing (writerly?) ${ }^{15}$ Eden does not happen without consequences. David's feminization through hair-cropping and hair-dyeing is voluntary. Catherine guides his sexual will, and even though he is reluctant to embrace her dangerous ways, he nevertheless agrees to all of her propositions. The Garden of Eden portrays female-on-male sodomy, "which novelists seldom choose to do" (Fantina 2003: 97). Hemingway's construction of Catherine as a dominant woman definitely upsets the traditional gender binarism, if it does not "altogether provide an alternative to patriarchal dominance" (Ibid: 100)? Using hair and racial fetishes, the novel depicts phallic women who penetrate male bodies (Ibid: 103). No wonder, then, that David is not ready to show this emasculated identity before others. ${ }^{16} \mathrm{He}$ does not feel like violating private - public opposition in his fear of threatened hegemony, emasculation and further loss of male identity. At the same time, his passivity and dependency on women makes evident his ambivalent attitude to sexuality. Namely, Hemingway makes "the connection between androgynous corruptions with wives and mistresses and the author's writing strengths" explicit (Spilka

\footnotetext{
${ }^{15}$ This is an allusion to Roland Barthes' differentiation between the writerly and the readerly text. Namely, "the writerly text is ourselves writing" and it is a perpetual present. According to Barthes, "to rewrite the writerly text would consist only in disseminating it, in dispersing it within the field of infinite difference." By referring to Barthes here, we are trying to emphasize David and Catherine`s roles as producers of their text, whereby they as readers would no longer be only consumers (1999: 31).

${ }^{16}$ See footnote no. 9.
} 
1995: 296). Hemingway-David is open to the manipulation of his wives and mistresses whom he desperately needs and with whom he secretly identifies (Ibid: 299). Any real resistance to Catherine that David is able to build is again through his writing, but with Marita this time round. The published novel's version can be read as "a travesty of female selfhood, a betrayal of truly androgynous love and a denial of the primacy of the female within the male for his own independent creativity" (Ibid: 310). The Scribner's edition thus simplifies the mysteries of the writer's craft, which Hemingway cannot have been happy with.

\section{Mirror images}

The Garden of Eden boasts multiple mirror images. Firstly, Hemingway reflects the context of modernism in its pervasive concern with multiple gender issues. He is known for the radical subversion of some $20^{\text {th }}$ century forms of patriarchy, though the question as to whether he had a conscious desire to do this still remains unresolved (Fantina 2003: 104). His work often mirrors his awareness of the prevailing social codes, movements, biology questions of women's hysteria and men's neurasthenia, etc. (Barlowe 2000: 128).

The two secret muses he cherished so much within himself affirm various theories of alter egos and doppelgangers. For one, David, Catherine and Marita use one another as reflections of their individual or collective qualities or states of mind. Hence, after the first sea change David and Catherine look at themselves together in the mirror (Hemingway 2003: 43), then Catherine looks at herself in the mirror critically (Ibid: 48). At a different point, the big hairdresser's mirror reflects what she sees in her hand mirror (Ibid: 80). Catherine's belief that they need a big mirror in the bar (Ibid: 102) where they spend a lot of time eating and drinking is an unmistakable trace of the protagonists' need to find evidence of their rot in the visual image any mirror offers back to them. After having an insatiable urge to make love to Marita, Catherine roams the mirror for some expression but does not find any (Ibid: 115). David looks at himself in the bathroom mirror in utter disbelief at what he has done. His sense of real identity is shattered with his mirror look (Ibid: 84). David repeatedly looks in the mirror as if attempting to detect the signs of his corruption in the glass, but he sees no external transformation. Hemingway's use of 
the face in the mirror as "an objectification of the artist's ethical dilemma" is ample here and elsewhere in his fiction (Fleming 1996b: 11). Mirror as a powerful recurring symbol cannot always be an accurate reflector of inner feelings. It may provide a reflection of reality that is sometimes more cruel than characters' pictures of themselves. The characters' obsession with an idea of the reflected image will not allow them to look at each other for any signs of either physical or psychological transformation (Ibid: 144). Watching the emotions is not the same as being actively involved in them.

As Rubinstein aptly maintains, "the self is also an audience" (in Elkins 2000: 94). Therefore, clothes can also be used as a manipulative technique to view ourselves as social objects. Hemingway used the language of clothing together with his writing to send diverse messages to his audience. ${ }^{17}$ The increasingly masculinized, androgynous women of The Garden of Eden pose a threat to a unified picture of Hemingway as a sole painter of exclusively male world void of women. In this respect, Catherine's artistic inclinations can be perceived in her constant reading, as well as her urging desire to paint (Hemingway 2003: 53). She is unable to get out of selfish acting as if she were her own painting (Ibid: 54).

Finally, the novel reflects back manifold images the characters create at its very readers. "Hemingway's readers are positioned to watch" (Strychacz 2003: 9) the multiplicity of The Garden of Eden's images of manhood-fashioning. Gender with Hemingway becomes a multifaceted concept (Ibid: 13), thus creating a doubling, if not quadrupling, of gazes. For instance, a new sense of Catherine's self is based on how she is looked at. Her theatre of self-representation (e.g. dyeing and shortening her hair) becomes "a drama of her own making." Her command of the gazes directed at her refuses the traditional staging of the woman as a prized object of the male gaze and male desire. In his passivity, David mostly functions as "an evaluating audience of her gender-switching," stressing once again the performer - audience contrast (Ibid: 217-218). After she sleeps with Marita, we witness a withdrawal of David's gaze and an unproductive mirror gaze of her own. This is all to stress the flexibility of roles produced socially and theatrically, whereby the protagonists' quest for masculine

\footnotetext{
${ }^{17}$ One instance of manipulation with clothing: Catherine is dressed the same as David, in fisherman's shirt, so that they look like brother and sister, but she goes to church appropriately dressed so no one could disapprove (Hemingway 2003: 6).
} 
identity only reveals "the profound loss of center" they are forced to keep negotiating (Ibid: 220).

\section{Conclusion: Ambivalence}

To our mind, "Hemingway remains notoriously difficult to pigeonhole" (Fantina 2005: 150). His investigation of topics such as emotional closeness or distance, loneliness and writer's isolation, beauty, writing, artistic paralysis, failed communication between men and women, marital betrayal and sexual roleplaying, abundantly shows that he may even be viewed as "a misunderstood feminist" (Ibid, 156). The stance he chooses to employ regarding gender is ambivalent and impossible to determine. The theme of sexual ambiguity affirms Butler's notions of gender as a series of acts which are incessantly renewed and revised (2004: 903). Though this notion is rather disquieting, it is no less true for it.

The Garden of Eden is a self-reflexive novel that explores new territory and possibly marks "the beginning of Hemingway's postmodernism" (Fleming 1996a: 147). It parades gazes at himself as a writer and as a man, gazes at its characters and readers alike. Albeit a shred of his Victorian conservatism in this novel, Hemingway demonstrates that he is unafraid to artistically cope with still controversial topics such as sexual role-playing, androgyny, self-destruction and self-deception. In his ability to depict the woman's point of view he proves to be "a resisting writer" (Spilka 1995: 300), just to spite those who still read his works as resisting readers. ${ }^{18}$

\section{References}

Barlowe, J. (2000). Hemingway's Gender Training. In: Wagner-Martin, L. (ed.). A Historical Guide to Ernest Hemingway. Oxford \& New York: Oxford University Press, 117-153.

Barthes, R. (1999). From S/Z. In: Wolfreys, J. (ed.). Literary Theories: A Reader and a Guide. Edinburgh: Edinburgh University Press, 30-45.

\footnotetext{
${ }^{18}$ An allusion to Judith Fetterley's groundbreaking book The Resisting Reader: A Feminist Approach to American Fiction, which primarily sees Hemingway as a misogynist writer.
} 
Burwell, R. M. (1993). Hemingway's Garden of Eden: Resistance of Things Past and Protecting the Masculine Text. Texas Studies in Literature and Language, Vol. 35, No. 2, Anxieties of Identity in American Writing, $198-225$.

Butler, J. (2004). Performative Acts and Gender Constitution. In: Rivkin, J. and Ryan, M. (eds.). Literary Theory: An Anthology. Oxford: Blackwell Publishing, 900-911.

Comley, N. R. (2002). The Light from Hemingway's Garden: Regendering Papa. In: Broer, L. R. and Holland, G. (eds.). Hemingway and Women: Female Critics and the Female Voice. Tuscaloosa and London: The University of Alabama Press, 204-217.

Comley, N. R. and Scholes, R. (1992). Tribal Things: Hemingway's Erotics of Truth. NOVEL: A Forum on Fiction, Vol. 25, No. 3, 268-285.

Elkins, M. (2000). The Fashion of Machismo. In: Wagner-Martin, L. (ed.). A Historical Guide to Ernest Hemingway. Oxford \& New York: Oxford University Press, 93-115.

Fantina, R. (2005). Ernest Hemingway: Machismo and Masochism. New York: Palgrave Macmillan.

Fleming, R. E. (1989). The Endings of Hemingway's Garden of Eden. American Literature, Vol. 61, No. 2, 261-270.

Fleming, R. E. (1996a). Hemingway's Late Fiction: Breaking New Ground. In: Donaldson, S. (ed.). The Cambridge Companion to Hemingway. Cambridge: Cambridge University Press, 128-148.

Fleming, R. E. (1996b). The Face in the Mirror - Hemingway's Writers. Tuscaloosa \& London: The University of Alabama Press.

Hemingway, E. (2003). The Garden of Eden. New York: Scribner.

Jung, C. G. (2003). Marriage as a Psychological Relationship. In: Jung, C. G. Aspects of the Feminine. London \& New York: Routledge Classics, 46-61.

Kennedy, J. G. (1991). Hemingway's Gender Trouble. American Literature, Vol. 63, No. 2, 187-207.

Lovell Strong, A. (2002). "Go to sleep, Devil:" The Awakening of Catherine's Feminism in The Garden of Eden. In: Broer, L. R. and Holland, G. (eds.). Hemingway and Women: Female Critics and the Female Voice. Tuscaloosa and London: The University of Alabama Press, 190-203.

Sanderson, R. (1996). Hemingway and Gender History. In: Donaldson, S. (ed.). The Cambridge Companion to Hemingway. Cambridge: Cambridge University Press, 170-196.

Spilka, M. (1987). Hemingway's Barbershop Quintet: "The Garden of Eden" Manuscript. NOVEL: A Forum on Fiction, Vol. 21, No. 1, 29-55. 
Spilka, M. (1995). Hemingway's Quarrel with Androgyny. Lincoln \& London: University of Nebraska Press.

Strychacz, T. (2003). Hemingway's Theaters of Masculinity. Baton Rouge: Louisiana State University Press.

Strychacz, T. (2008). Dangerous Masculinities - Conrad, Hemingway, and Lawrence. Gainesville, FL: University Press of Florida.

Wagner-Martin, L. (1991). Hemingway Regendered. NOVEL: A Forum on Fiction, Vol. 24, No. 3, 323-324.

Wagner-Martin, L. (2002). The Romance of Desire in Hemingway's Fiction. In: Broer, L. R. and Holland, G. (eds.). Hemingway and Women: Female Critics and the Female Voice. Tuscaloosa and London: The University of Alabama Press, 54-69.

Received: 1 October, 2013

Accepted for publication: 25 October, 2013

Александра Жежељ Коцић

ЕРНЕСТ ХЕМИНГВЕЈ: РЕКОНЦЕПТУАЛИЗАЦИЈА РОДА

\section{Сажетак}

Овај рад се бави начином на који роман Ернеста Хемингвеја Рајски врт разуме концепт рода. Наиме, занима нас репрезентација човековог идентитета у Хемингвејевом тексту, а нарочито конструисаност Хемингвејевих јунака по линијама рода и сексуалног понашања. Хемингвејева заинтересованост за трансгресивну сексуалност - с нагласком на замени родних улога (gender-switching) - очигледно показује свесни искорак ка субверзији традиционално патријархалних идеја за које се обично мисли да Хемингвеј заговара. Његово испитивање граничних подручја улази у специфични дијалог с разноликим представама мушкараца и жена. Иако је веза између писања/креативности и сексуалности/жеље одувек присутна у Хемингвејевом делу, за Рајски врт се нарочито каже да истражује пишчеву храброст у свакодневној борби да пренебрегне срамне зависности и пасивности користећи при том своје животне боли.

Кључне речи: Ернест Хемингвеј, род, прекорачење, субверзија, преиспитивање, гранична подручја. 